\title{
RIAU MALAY IDENTITY POLITICS
}

\author{
M. Rafi $\left({ }^{1 *}\right)$, Eko Priyo Purnomo $\left({ }^{2}\right)$, Baskoro Wicaksono $\left({ }^{3}\right)$ \\ 12 Department of Government Affairs and Administrations, Jusuf Kalla School of Government, \\ Universitas Muhammadiyah Yogyakarta, Indonesia. \\ 3 Department of Government Science, Universitas Riau, Indonesia.
}

\begin{tabular}{ll} 
ARTICLE INFORMATION \\
\hline Submitted & $: 29^{\text {th }}$ December, 2019 \\
Review & $: 01^{\text {st }}$ February, 2020 \\
Accepted & $: 04^{\text {th }}$ May, 2020 \\
Published & $: 1^{\text {st }}$ June, 2020 \\
Available Online & $:$ June, 2020 \\
\hline KEYWORDS \\
\hline Politics; Identity; Malay; Riau \\
CORRESPONDENCE
\end{tabular}

*E-mail: m.rafi.psc19@mail.umy.ac.id

\begin{abstract}
A B S T R A C T
This article is a study of the process of the rise of Riau Malay Identity Politics when it was previously marginalized in the New Order era. The purpose of this article is to look at the stages in the formation of identity politics in restoring the glory of Malay culture in Riau province. This research is descriptive-explorative library research that explains and explores ideas about Riau Malay identity politics by answering questions in problems identified based on reading results and data interpretation related to the research theme. The results showed that after the reforms, the political elite of the Riau Province government tried to strengthen Malay identity with a variety of policies that were disseminated. Then, the negative views that were often directed towards ethnic Malay in the past, were rectified again by giving Islamic values to all the lives of the Malay people. Furthermore, the Local Government and the Riau Malay Customary Institution try to resocialize the importance of the use of Malay as the origin of Indonesian.
\end{abstract}

\section{A. INTRODUCTION}

T he issue of identity politics is a problem that is often discussed in Indonesia, because many things can be studied and analyzed through various perspectives. In essence, identity politics in Indonesia is more specific to the issue of race, culture, politics and local preferences expressed by the elite through the accumulation of their respective interests (A. Abdullah, 2017; Erman, 2018; Putra, 2019). Then, the politics of regional identity becomes more viscous because each region wants to be led by its sons and daughters (Alfarabi, 2019).

In general, the Malays in Southeast Asian countries are aware of the challenges they face together, and unlike the Malays in Indonesia who have their own individuality in displaying their culture, the ethnic Malays in Indonesia are bound together in their respective regions. And do not have the same psychological unity to fight. As a result of this local development, Malay identity in Indonesia has narrowed and developed independently. Malay identity preferences are often dictated by the circumstances they face and change according to the demands of the times.
Cultural and political pressure by the New Order government has caused the weakening of the Malay community in Indonesia. This situation was created because the New Order government carried out cultural homogenization, which contributed to Jawanization. Malay identity eroded until reform came (Alfarabi et al., 2019; Asrinaldi, 2018).

The transition period was a shift in the structure and governance of the Indonesian State under the leadership of President Soeharto. Policies that have traditionally been top-down have begun to be replaced by the process of regional autonomy that allows regions to have the power to regulate themselves. The Reformation period has given more space for the people of Indonesia to get support for national and national policies. Community participation in the determination of national and local policies is a direct democratic political system born of reform. The political system of direct elections allows voters to be active in deciding who needs to be considered a city representative. In this context, the regional identity becomes thicker 
because each region wants to be led by the sons of the region. The awareness of hosting in their own country is a problem that follows the age of independence in the reform era. This situation makes regional identity competitive and the topic being discussed in the context of local policy. Therefore, the birth of a regional autonomy strategy and a direct election political system have helped to raise awareness of Malay identity (Alfarabi et al., 2019; Alfarabi, 2019).

According to (Heywood, 2014), Identity Politics is a political style that seeks to fight group marginalization by embracing a positive and assertive sense of shared identity. Furthermore, according to Morowitz in (Prayetno, 2016), identity politics is a way to provide a clear line in determining who will be included and who will be rejected. Because the determination lines seem irreversible, then the status as a non-member member necessarily seems permanent. Making ethnic identity as a political commodity is a step to influence other parties in order to fulfill their desires. According to (Castells, 2010), there are three formations in building an identity, namely:

1. Legitimacy identity is the image of an institution that regulates the community, which rationalizes and maintains hegemony over social actors, such as state institutions that seek to improve the national identity of community members. In fact, the organization has gained credibility to do it.

2. Resistance identity is a cycle of the formation of identity by social members who are under pressure because of the dominance and stereotypes by other parties to form an opposition and create an identity that is different from those who govern, with a view of the existence of a community.

3. Project identity is an identity in which cultural members form a new identity that can determine a new position in society and change the overall structure of society.

Identity politics is an ideology that exists in every ethnicity. Its existence is latent and potential and at any time, can come to the surface as a dominant political force (Salim, 2015). The search for identity, both collectively and individually, becomes the most basic source of the meaning of the fundamental source of meaning. The search for identity and purpose is not something entirely new, because identity, especially based on religion and ethnicity, has become the root meaning of human life since civilization is present on earth. However, today, in a historical period marked by organizational destruction and institutional delegitimation, it has eliminated social movements that have a large impact and temporary cultural expression. In other words, although not the only one, identity is the main source of meaning. People increasingly organize, organize their meaning of life not around what they do, but, rather based on what they believe (Hemay \& Munandar, 2016; Putra, 2019; Salim, 2015; Ulum et al., 2017).

Identity politics, which are often present on the surface of Indonesia's modern history, must be treated and defended carefully by contextual logic that is interpreted accurately and intelligently (Habibi, 2017). Tribal sentiments can only have a positive effect when confronted with the image of figures, which means that someone will support a candidate, whatever his tribe or it can also be said that the contribution of each factor can be either negative or positive (Hemay \& Munandar, 2016), The emergence of ethnic influence as a political force slowly changes the control of the state and the ruling bureaucrat class (Salim, 2015). Selembayung, as a characteristic of Malay identity, actually moves more freely among its user groups so that uniformity and exclusion are not successful (Salam, 2017), The emergence of identity politics mainly used to strive to change social, political and economic structures that do not support the lives of Malay ethnic groups (Marnelly, 2017; Venus et al., 2019).

The process of intellectual Malay Islamic traditions cannot be separated from the process of transmitting and disseminating Islamic teachings and ideas, which always involves a kind of "intellectual network" between the scholars and intellectuals as a whole (Jaya, 2018; Ris'an Rusli, 2018), As far as the political aspects are concerned, the problem of regionalism or main opinion in people's lives clearly creates a structure for the operationalization of identity politics, which can be seen in many conditions that arise in culture, as evidenced by a series of collisions (Ulum et al., 2017), identity is politicized by extreme interpretations and requires support from people who feel the same, whether in gender, nationality, beliefs or other components (A. Abdullah, 2017; Syu'ib, 2017).

The survival of the supremacy of Malay culture is a big challenge because although it is still active, the current position of Malay is less strategic and its influence is starting to decline (I. Abdullah, 2017; Sanusi, 2017), The reforms have allowed the Riau Malay population to continue to show their presence in their area (Alfarabi et al., 2019; Alfarabi, 2019; Alfarabi et al., 2019; Asrinaldi, 2018). Malay ethnicity as a community has the right to be involved in determining Malay political format, not a community that is part of a political system based on the royal ideology that tends to be authoritarian (Jaya, 2018; Marnelly, 2017), President Soeharto's rejection of the results of the 1985 Riau Governor election that won an indigenous son became a monument that is always remembered for the authoritarian attitude of the New Order, which had denied the 
will of the majority of the people of Riau (Hapsa, 2019), Malaysia and Indonesia, when this seems to lack understanding of the historical background of the two countries. Most of the recent social and corporate challenges arose from cultural confusion, so even a small concern will cause fires and flames that do not die out quickly (I. Abdullah, 2017; Zed, 2015).

An identity can be essential, universal, and eternal. However, the building of identity cannot be separated from socio-cultural influences (Riswari, 2019), In the meaning of modernity, Malay civilization, which has established its inheritance, will become more sophisticated and at the same time, be able to dominate the great civilization of the world if it can change something from domination to hegemonic culture (Sanusi, 2017), Malays want their heritage protected by local government policy and not used for practical politics (Asrinaldi, 2018).

Malay Modern Ujungbatu Riau is a community of citizenship characterized by attitudes of people in the form of mutual trust, mutual reconciliation, capacity for collaboration, faith, duty, unity, deliberation, solidarity, and cooperation (Yosi Malasari, 2017), Ethnic Bugis, who live in Indragiri Hilir Regency is ethnic refugees, with a total population of 150,816 people, occupying the third rank among ethnic Malay and Banjar ethnic groups. However, ethnic Bugis are able to manage power relations in an appropriate manner. Evidence of the role of the Bugis ethnic group in Inhil has strategic positions in various fields, especially in the legislative body (Hapsa, 2019), LAM Riau implements the mechanism of forming Malay cultural values, the practice of Malay cultural values in the community, and the implementation of Malay building architecture. Efforts made by LAM Riau have not yet reached the level of full stakeholders, but only in the form of recommendations that do not always represent input for these stakeholders (M.Zainuddin, 2018). The government in the Malay Malay environment places more emphasis on governance based on ideals Islam (Alfarabi et al., 2019; Jaya, 2018), Leaders must include all elements, be transparent and accountable in their decision making, ensure that justice is served, and pay attention to the public, political, and economic interests of the community (Syamsuadi, 2018).

Previous studies on Malay identity and culture have illustrated that Malay culture has significance for Riau and Indonesia, Riau Malay Identity Politics presented in the post-reform era is interesting to study because of the selection of cultural symbols identified as regional identities to socialize Malay identity. The identity in practice requires an instrument to distinguish and at the same time, to provide similarity with who is called Malay and who is not. Studying the identity politics used by the Riau Malay people to display their ethnicity, indirectly also examines the Riau Malay process in building its long-marginalized local identity. The creation of identity also reflects the values sought by Malay culture (Alfarabi et al., 2019; Alfarabi et al., 2019). One of the provinces which are in the process of displaying Malay identity politics is Riau. Riau Province is a region that is considered to have a strong Malay history. Malay history in Riau has strong ties with Malay in Riau Islands, Johor Malay, Malacca Malay, Singapore Malay, and Mining Malay. Efforts to build a Malay identity in Riau are contained in the Vision of Riau 2020 which wants to make Riau a center of Malay culture, not only in Indonesia but also in Southeast Asia (Affandi, 2018; Syamsuadi, 2018; Syu’ib, 2017).

Table 1. Ethnicities in Riau Province

\begin{tabular}{cccc}
\hline No & Tribe & Amount & Percentage (\%) \\
\hline 1 & Melayu & 2.103 .659 & $37,74 \%$ \\
2 & Jawa & 1.431 .598 & $25,05 \%$ \\
3 & Minang & 672.621 & $11,26 \%$ \\
4 & Batak & 400.837 & $7,31 \%$ \\
5 & Banjar & 191.787 & $3,78 \%$ \\
6 & Tionghoa & 188.897 & $3,72 \%$ \\
7 & Bugis & 139.26 & $2,27 \%$ \\
8 & Sunda & 103.012 & $1,6 \%$ \\
\hline & Amount & $\mathbf{5 . 7 2 6 . 2 4 1}$ & $\mathbf{1 0 0} \%$ \\
\hline
\end{tabular}

The table above shows that Riau Province has various ethnic tribes dominated by Malay tribes, efforts to build Riau Malay identity identity are contained in Riau Vision 2020 "The realization of Riau Province as the Center of Malay Economy and Culture in a Religious, Prosperous, Born and Inner Community
Environment in Southeast Asia in 2020 ", Riau Vision 2020 becomes a dream and aspiration to restore the glory of Malay culture with integrity in Riau and the rising degree of Riau Malay people after a long time of Malay identity sinking under pressure from the New Order era central government (Syu'ib, 2017). This research aims 
and focused on examining how Malay identity politics in Riau in realizing a Malay culture of integrity based on three processes of formation in building an identity according to Castels, namely Legitimacy Identity, Resistance Identity, and Project Identity.

\section{B. METHOD}

T his research is descriptive-explorative library research. Explain and explore ideas about Riau Malay identity politics in the process of reviving Malay cultural identity. This study uses a qualitative method by answering questions in the formulation of a predetermined problem based on reading and interpretation of data relating to the theme under study, consisting of primary and secondary sources. Primary sources consist of national and international scientific journals and also books that directly refer to the research theme. While the secondary sources are the sources mentioned above but are not directly related to the theme (Hermawan, 2019).

Research collection techniques are reading, recording, selecting data, and categorizing data. In detail, the activity begins with reading the literature related to research, then proceed with recording the materials to expand the information needed. The next step was selecting the data that had been obtained. As the final stage, data categorization is carried out to be included in the appropriate sub-sections (Albi Anggito, 2018).
To test the data obtained, qualitative descriptive analysis is used by reducing data, presenting data, and drawing conclusions. The main concern in this research will be directed to the study of Riau Malay identity politics in the process of building a collective identity of Malay people.

\section{RESULTS AND DISCUSSION}

\section{Riau Malay Legitimacy Identity}

A fter the reform period, the political elite of the Riau provincial government began to try to strengthen and show their true identities, and various discourses were formed through policy and disseminated to portray Malay character in Riau.

The Riau Malay Customary Institution is dedicated to protecting and preserving the legacy of the Malay symbol and working with the Riau Provincial Government in fulfilling the Vision of the Riau 2020 Mission. 1 of 2012 in Chapter IX Article 11, Riau LAM plays a role in:

1. Conduct an inventory of regional customs, arts, and socio-cultural values.

2. Conduct an inventory of cultural assets and historical relics of the region.

3. Conduct planning and implementation of management activities and the development of traditional activities, arts/socio-cultural values of the region, and Arranging plans and implementing maintenance activities and utilizing cultural assets and the historical relics of the region.

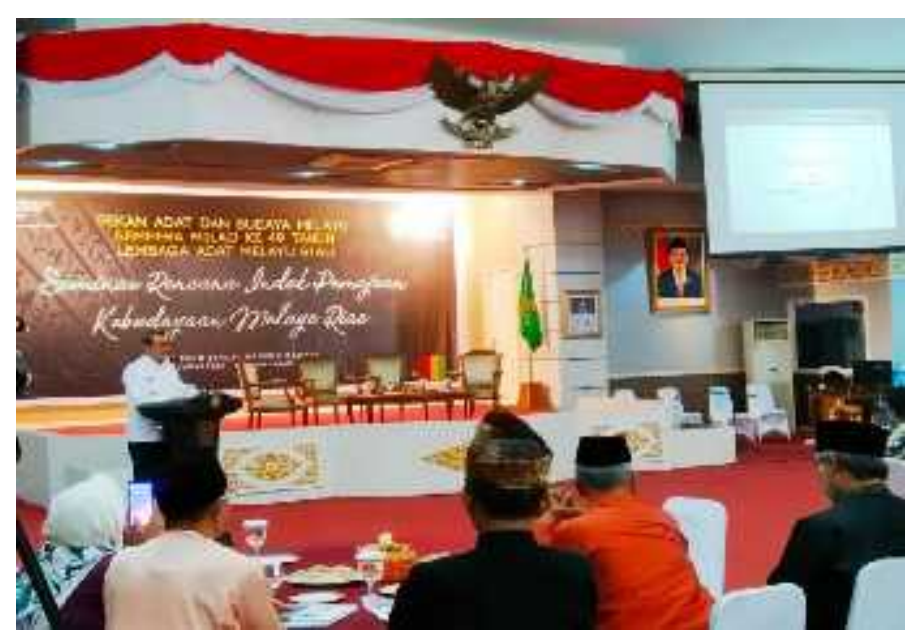

Figure 1. The Riau Malay Customary Institution and the Riau Provincial Government work together to strengthen Malay culture (Source: datariau.com 2019)

The collaboration between Riau Malay Customary Institution and the regional government of Riau Province is an identity of legitimacy that is seen in the policymaking process, besides that, The Riau Malay
Customary Institution has had an important role in the preparation of regional regulations, and has been involved in the process of making regulations regions, especially regional regulations regarding inheritance or practices of 
Malay communities in Riau (Affandi, 2018; Syu'ib, 2017).

Furthermore, the Riau Provincial Government wants to maintain and develop Malay culture as a collective identity of the people of Riau, through Riau Provincial Regulation No. 1 of 2012 concerning the Riau Malay Customary Institution in chapter $\mathrm{V}$ Article 6 regarding Purposes, it is stated that several objectives of the Riau Malay Customary Institution are:

1. Riau Malay Customary Institution aims to explore, foster, preserve, preserve, and develop traditional values and social, cultural values as a basis for strengthening and strengthening the identity of the Malay community.

2. Riau Malay Customary Institution aims to protect and defend the traditional and constitutional rights of indigenous peoples, and socio-cultural values in the interests of enhancing the outward and inner welfare of the Riau Malay community.

3. Riau Malay Customary Institution aims at realizing indigenous peoples and advanced, just, and prosperous socio-cultural values in the civil social order.

Together with the end of the New Order Government, Riau Province immediately established the vision and mission of Riau Province, which was extended from 2020 to 2025. The extension of Riau's vision and mission 5 years in the future, is in accordance with Law number 17 of 2007, where the Regional LongTerm Development Plan is equated with the National Long-Term Development Plan of 2025 which is contained in the Riau Vision Vision 2025, namely: "The realization of Riau Province as the Center of Malay Economy and Culture in a religious, prosperous and prosperous society born in Southeast Asia in 2025".

\section{Riau Malay Resistance Identity}

In the past, there were negative views pinned to the Malay community. Each ethnic group naturally wanted to display a positive image that was even better than other ethnic groups. Ethnic groups with negative identities try their best to erase negative stereotypes so that ethnic images can be improved. The same situation was carried out by Riau Malay postreformers, who tried hard to change their negative views on their ethnic groups. One of them is by rectifying the negative stereotypes inherent in the Riau Malay character. This discourse was carried out because, in the past, there was a negative view pinned on Malay in the past, namely 'Malays are lazy and not hardworking people'. This expression eventually led to a negative Malay identity paradigm. In general, this negative view is tried to be eliminated through the discourse on the politics of Malay identity. The process carried out in changing this view is by giving Islamic values to all Malay people's life which is often called 'Melayunisasi', the concept of melayunisasi is displayed in the selembayung in the local government building and traditional institutions in Riau.

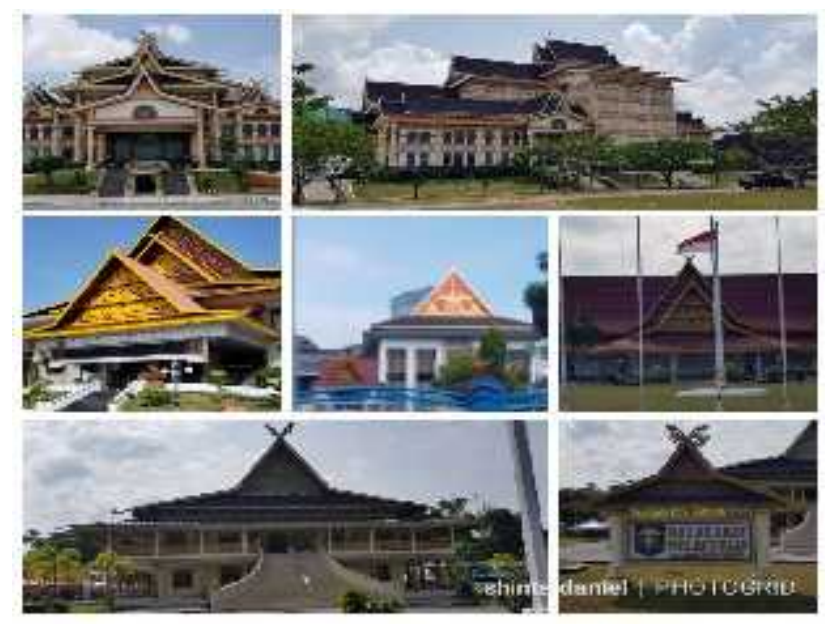

Figure 2. The use of Selembayung in government buildings and traditional institutions (Source: shintadaniel.wordpress.com 2019)

In the picture above, it can be seen that Selembayung as identification in the efforts made by Malays to show their host in Riau. This policy was implemented after the euphoria of independence reform and the expansion of regional autonomy. Displaying Malay identity as a 
whole is the fastest step to show Malay life in Riau. Selembayung is the most impressive visual sign to display because it is clearly visible on the roof of the building. In fact, Malay finds Selembayung as a Malay identity politics that has philosophical meaning.

Selembayung can be seen in two ways: Islam and sociology. First selembayung is an embodiment of rehal the holder of the qur'an at the time of the recite. The essence of this is the openness of the Malay community to the acceptance of outsiders who come to their area. The definition of openness is taken from the nature of open mind. Such transparency is a description of the nature of the Malays who, according to Islamic teachings, want to stay in touch. Second, selembayung is understood as a picture of "hablumminnannas" which is reflected in wood that is crossed and "hablumminallah" which is reflected from wood that is perpendicular to the sky. The implication is that Malayan culture maintains bonds with fellow humans and connections with God. In a sociological approach, Selembayung is called a symbol and a summary of the characteristics of the Malays.

\section{Riau Malay Project Identity}

The introduction of regional autonomy after the fall of the New Order system is interesting in strengthening regional identity. Autonomy is even defined as indigenous ethnic rights in the region, thus ignoring other ethnic rights as migrants. This has been done by the Riau Malay community when the beginning of the reforms demanded that the central government pay more attention to development in Riau, especially with the natural resources owned by this region, but cannot be enjoyed by the people. As a result of this political phenomenon, three demands emerged from Riau Malay leaders such as Tabrani Rab, Al Azhar and so on to urge the central government to grant the widest possible autonomy, the formation of federalism or Riau independent. Even the discourse for the "the independent riau movement" is quite prominent in these demands, causing friction with the security forces in this area. As a basis for the implementation of regional autonomy as widely as possible in Indonesia, communities increasingly strengthen their political identities.

Various local political movements emerged in almost every region in Indonesia. Riau is no exception, even the issue of the son of the region is an issue that is often raised, especially in policy making by local governments. Common problems of sons and daughters in this region are related to priority policies or positive policies implemented by local governments to provide space and space for ethnic and non-ethnic migrants in economic, political, governance, and socio-cultural activities.

Malay society in general is the same as Islam, Islam is the most strict ethnic boundaries created by Malay to separate those who belong to Malay and those who do not. Aside from being a prerequisite for Islam, Islam is also a benchmark for the value of the behavior of the Malays themselves. There is pride in the Malay community with their Islamic identity. The role of Islam in Malay culture is so strong that when Islam is disturbed, it also means that one's Malayness is also disturbed. The quality of Islam in the Malay aspect is shown by the example of someone who came out of Islam, then automatically considered out of Malay itself. The same thing also applies when a person converts to Islam in Malay land, in general the community will say that person has become Malay. The results of previous studies found that the Malay community in Pekanbaru Riau was strongly held not to separate between Islam and Malay.

Islam is the source of reference, and Malay is the manifestation. All Malays' actions must be based on Islamic teachings. So starting from thinking to behaving everything is a manifestation of Islamic values. So it can be said that Islam and Malay are one, Malay which is identical with Islam has long been used as the identity of the Malay community. It's just that during the New Order government, this identity only appeared limited to religious status. After the collapse of the New Order, this identity was revived to reject the negative stereotypes of Malay society. Thirtytwo years of oppression during the New Order era not only marginalized Malay identity, but also gave rise to the stereotype that Malay people are lazy, do not like to work hard, and like to pretend to be.

Identifying Malay is Islam and Islam is Malay is a method used to refute negative stereotypes before, Malay people who are similar to Islam will not practice practices that are contrary to Islamic teachings, such as laziness and others (Alfarabi et al., 2019). Speaking Malay is the next criterion that someone is said to be Malay. Malay is an identity politics to show one's Malayness. 


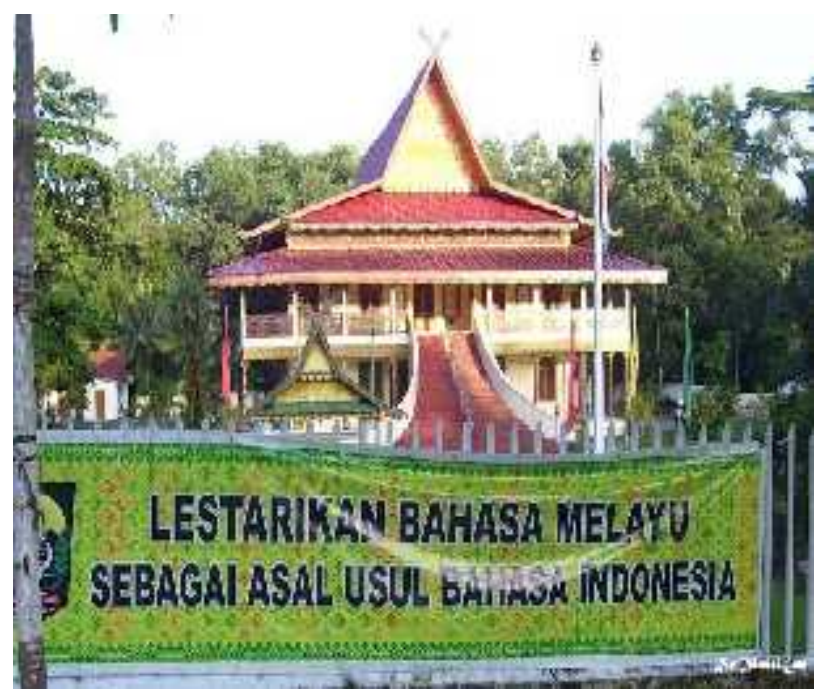

Figure 3. Preservation of Malay as a way of advancing Riau Malay culture (Source: Riautelevisi.com 2019)

Malay can be understood in three points of view. First, Malay is seen from a philosophical point of view, language use, and from a dialect perspective. Malay identity in Riau can be seen from these three perspectives. Philosophically, the Malay language is a consequence of the choice of Malays to choose Islam as something inseparable from their lives. The presence of Islam had an impact on the entire Malay culture, including the use of language in it. Malay dialect is the spread of Islamic ideals so that Malay words prevent controversy. The advice taught by Raja Ali Haji in Gurindam twelve also provides guidance for members of the Malay community about how Malays should behave and behave as desired by Malay custom. Gurindam Twelve contains twelve chapters. As an illustration, the following article excerpts:

If you want to know people who are national

Look at the mind and language

If you want to get to know people who are happy

so caring for nothing

If you want to get to know a noble person

Look at his behavior

If you want to know people who have knowledge

Asking and learning is not bored

If you want to get to know someone who is intelligent

In the world take stock

If you want to get to know a person who

has a good temperament

Look at it when mixed with crowded people

Gurindam Temple above teaches that a person behaves and behaves as a Malay cultural custom. The teaching is that in a nation or ethnicity or in a group or organization, one must have a good mind and language. Good language and language have been exemplified in religion and customs. Moreover, the customs of Malay culture, the values of customs are taken from religious values. From a philosophical point of view, the Malay language is considered as a radiant of manners, where the inner picture of the Malay community is painted in the appearance of the language.

Furthermore, the second viewpoint of the Malay language is seen from the use of the word. The Malay Languange community is full of symbolism. The Malay language phrase often does not refer directly to what is said but is full of imagery. Symbolism in Malay is associated with a calm tendency and a feeling of cultural diversity, which prevents conflict. There is a concern that when a word is used directly on someone, it will offend the person. This has caused many Malay proverbs to be found in parables. When associated with language as moral, preserving Malay is part of the cultural characteristics of Malay itself. Society believes that language damage results in the destruction of the nation. The third perspective in understanding Malay as an identity politics is a dialect. Someone is considered to speak Malay based on the dialect used in conversation. Dialect is a way to say words and phrases in daily communication. The same words and sentences are possible to be pronounced differently. Riau Malay is divided into two dialects. Riau Malay with suffix $e$ and Malay with suffix 0 .

Furthermore, a person is said to be Malay when his behavior reflects the Malay culture. Just 
as the criteria of Islamic religious identity and Malay language have one layer of meaning, the perspective of Malay culture can also be understood because all Malay people's behavior is based on Islamic values. The daily actions of a person who is said to be Malay must be encouraged by the teachings of the Qur'an and the Sunnah of the Prophet, from the smallest areas to the wider community.

Based on the description, it can be seen that Riau Malay culture is a national identity that must be maintained because when someone who lives in Riau Province does not recognize Malay culture as a whole, it will cause a cultural identity crisis. Then, someone who can speak Malay, he will have a higher political value in the eyes of the people of Riau because Malay is considered to be a spotlight on politeness and an inner image of the Malay community that is painted in a language display.

In general, the Riau people believe that Malay people are those who speak Malay and embrace Islam, while those who do not embrace Islam and do not speak Malay cannot be said to be Malay. This condition is following one of the Malay proverbs "If you want to know the people of the nation, look at the language". Therefore it can be understood that Islam and the Malay Language are the true identities of the Riau Malay people.

Furthermore, the existence of Selembayung on the roof of community houses, government buildings, and offices of traditional institutions is a message and one of the political attributes of identity that has been communicated to show Malay identity in Riau. In addition to showing ethnic identity, Selembayung is part of supporting the Vision of Riau 2020, one of which is to become the center of Malay culture in Southeast Asia, the Government in Riau Province believes that displaying Malay identity physically is the fastest step to show the existence of Malay in Riau.

Culture and attributes that are socialized to the people of Riau then have an impact on the term native sons and Malays who are more entitled to hold strategic positions in government. The use of symbols and Malay cultural campaigns as identity aims to improve the fate of the Malays in their homeland.

\section{CONCLUSIONS}

$\mathrm{T}$ he politics of Riau Malay Identity in realizing Malay culture with integrity can be seen from the three phases of identity creation that have passed, namely the Identity of Riau Malay Legitimacy through the Riau Malayan Customary Institution dedicated to protecting, developing traditions, preserving Malay culture and collaborating with the Riau Provincial Government in fulfilling the Vision Riau 2020, Furthermore, the Riau Malay Project Identity can be seen from the Identification of Malay as Islam and Islam as Malay, which is a method used to refute these negative stereotypes. Lazy and pretentious are against Islamic teachings. Malay society that is identical with Islam will not carry out activities that are contrary to the teachings of Islam such as lazing and pretending like the views that have been directed before, and speaking Malay is a criterion for someone to be said to be Malay. Malay is an identity politics to show one's Malayness. Secondly, Riau Malay Resistant Identity is carried out when there is a negative view embedded in Malay in the past namely 'Malay is lazy and not hard-working' This expression eventually gives rise to a negative paradigm on Malay identity in general, negative views try to be eliminated through discourse Malay identity politics. The process carried out in changing this view is by giving Islamic values to all Malay people's lives, which are often called 'Melayunisasi', the concept of melayunisasi is displayed on selembayung in local government buildings and traditional institutions in Riau.

\section{E. ACKNOWLEDGEMENT}

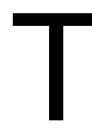
he authors say to the Leaders of the Masters of Government Affairs and Administrations of Yogyakarta MuhammaOdiyah University for the opportunity that has been given, both in the form of assignments and other support so that the author can studying on campus dreamed of long ago. Not to forget the author also conveyed to Mr. Eko Priyo Purnomo, S.IP, M.Sc, M.Res, Ph.D. for all the support and advice that has been given. Especially to Mr. Baskoro Wicaksono, S. IP, M.IP, thanks for the motivation and inspiration that has been given. May this article be a starting point for writers to start other writings of higher quality in the future. Hopefully, the knowledge taught can be charity Jariyah for him.

\section{REFERENCES}

Abdullah, A. (2017). Membaca Komunikasi Politik Gerakan Aksi Bela Islam 212: Antara Politik Identitas Dan ljtihad Politik Alternatif. Jurnal An-Nida' (Pemikiran Islam), 41(2), 202-212.

Abdullah, I. (2017). Glokalisasi Identitas Melayu: Potensi Dan Tantang Budaya Dalam Reproduksi Kemelayuan. Jurnal Universitas Gadjah Mada, 1(2), 1-7.

Affandi, S. A. (2018). Kapabilitas Lembaga Adat Melayu Riau Dalam Mewujudkan Visi Misi Riau 2020. 
Retrieved from www.repository.umy.ac.id

Albi Anggito, J. S. (2018). Metodologi Penelitian Kualitatif. Jawa Barat: CV Jejak

Alfarabi. (2019). Simbol Eksistensi Identitas Etnik Melayu Riau Di Pekanbaru. Jurnal Kaganga, 3(1), 67-77.

Alfarabi, Venus Antar, Syafirah Nuryah Asri, \& Salam Noor Efni. (2019). Elite Lokal Dan Upaya Pembentukan Wajah Baru Identitas Melayu Di Indonesia Pascareformasi. Jurnal Akademika, 89(3), 143-154.

Alfarabi, Venus Antar, Syafirah Nuryah Asri, \& Salam Noor Efni. (2019). Rekonstruksi Stereotip Negatif Etnik Melayu. Jurnal Manajemen Komunikasi, 3(2), 131-141.

Alfarabi, Venus Antar, Syafirah Nuryah Asri, \& Salam Noor Efni. (2019). Media Identitas Melayu Pascareformasi Di Indonesia. International Journal Of Multicultural And Multireligious Understanding, 6(1), 21-31.

Asrinaldi, A. (2018). Dimensi Kekuasaan Penghulu Adat Melayu Riau Dalam Pelaksanaan Demokrasi Lokal. Jurnal Antropologi: Isu-Isu Sosial Budaya, 20(1), 57-69.

Castells, M. (2010). The Power Of Identity. Chicester, United Kingdom: John Wiley And Sons Ltd.

Erman, M. A. (2018). Politik Identitas Dan Negara Bangsa Di Riau. Retrieved From www.unri.ac.Id

Habibi, M. (2017). Analisis Politik Identitas Di Indonesia. Jurnal Universitas Muhammadiyah Yogyakarta, 1(3), 1-22.

Hapsa, Purnomo Eko Priyo. (2019). Relasi Kuasa Identitas Etnis Dilembaga Legislatif Periode 20142019. Jurnal IImu Pemerintahan \& Kebijakan Publik, 3(1), 125-146.

Hemay, I., \& Munandar, A. (2016). Politik Identitas Dan Pencitraan Kandidat Gubernur Terhadap Perilaku Pemilih. Jurnal Kajian Politik Dan Masalah Pembangunan, 12(1), 1737-1748.

Hermawan, I. (2019). Metodologi Penelitian Pendidikan Kuantitatif, Kualitatif Dan Mexod Method. Kuningan: Hidayatul Quran Kuningan.

Heywood, A. (2014). Politik (Ke-4; A. L. Lazuardi, Ed.). Yogyakarta: Pustaka Pelajar.

Jaya, A. C. (2018). Konsep Nation-State Dalam Pemikiran Ideologi Politik Melayu Islam Pada Abad Ke-19 M ( Studi Pemikiran Abdullah Bin Abdul Kadir Munsyi ( 1787-1854). Jurnal Kebudayaan Dan Sastra Islam, XVIII (2), 139-151.

M.Zainuddin. (2018). Mekanisme Lembaga Adat Melayu Riau Dalam Melestarikan Wisata Budaya Di Provinsi Riau. Jurnal Agregasi, 6(1), 92-107.

Marnelly, T. R. (2017). Dinamika Sosial Budaya Masyarakat Melayu Pesisir (Studi Pengelolaan Madu Sialang Di Desa Rawa Mekar Jaya). Jurnal Antropologi: Isu-Isu Sosial Budaya, 19(2), 149154.

Prayetno. (2016). Menguji Hak Politik Dalam Kontestasi Politik; Analisis Terhadap Politik Identitas Etnis Di Desa Perdamaian, Kecamatan Binjai, Kabupatan Langkat. Jurnal Pusham Unimed, VII (2), 39-54.

Putra, D. K. (2019). Relevansi Politik Identitas Pemilih Muslim Dalam Pemilihan Gubernur Sumatra Utara Tahun 2018. Jurnal Antropologi: Isu-Isu Sosial Budaya, 21(2), 236-244.

Ris'an Rusli, Y. (2018). Relevansi Dan Kontinuitas Pemikiran Islam Klasik Dalam Intelektualisme Islam Melayu Nusantara. Jurnal IImiah Agama Dan Sosial Budaya Jawa, 3(2), 187-197. Https://Doi.Org/10.15575/Jw.V3i2.3582

Riswari, A. A. (2019). Komunitas Surabaya Wotagei: Sebuah Kajian Budaya Populer. Jurnal Antropologi: Isu-Isu Sosial Budaya, 21(1), 121-131.

Salam, Noor Efni. (2017). Penetapan Simbol Arsitektur Perumahan Masyarakat Riau (Selembayung) Sebagai Strategi Dalam Melestarikan Budaya Melayu. 2th Celscitech-UMRI 2017, 2, $29-37$.

Salim, K. (2015). Politik Identitas Di Maluku Utara Identity Politic In Maluku Utara. Jurnal Kajian Politik Dan Masalah Pembangunan, 11(2), 1667-1678.

Sanusi, I. (2017). Globalisai Melayu: Peluang Dan Tantangan Membangun Identitas Melayu Dalam Konteks Modernitas. Jurnal IImiah Pendidikan, 1(1), 39-57.

Syamsuadi, A. (2018). Membangun Demokrasi Pemerintahan Di Riau Dalam Perspektif Budaya Melayu. Jurnal Dinamika Pemerintahan, 1(1), 1-10.

Syu'ib. (2017). Lembaga Adat Melayu Riau Periode 2012-2017 Dalam Menegakkan Identitas Kolektif Masyarakat Riau. Jurnal Online Mahasiswa Fisipol Universitas Riau, 4(2), 1-16.

Ulum, B., Jannah, S. R., \& Arifullah, M. (2017). Hegemoni Sosial Dan Politik Identitas Putra Daerah Jambi. Jurnal Hukum Dan Perundangan Islam, 7(1), 225-249.

Yosi Malasari, C. D. (2017). Budaya Adat Pengantin Melayu Riau Dalam Pengembangan Budaya Kewarganegaraan. Jurnal Humanika, 24(1), 11-23.

Zed, M. (2015). Hubungan Indonesia-Malaysia: Perspektif Budaya Dan Keserumpunan Melayu Nusantara. Jurnal Tingkap, XI(2), 140-159. 